\title{
О БЛОКОВЫХ НЕОТЕКТОНИЧЕСКИХ ДВИЖЕНИЯХ НА ТЕРРИТОРИИ ЭСТОНИИ
}

За последние годы интерес к вопросам неотектоники в разных частях Советского Союза значительно возрос. На эту тему существует большое количество публикаций и проведен целый ряд региональных и межведомственных совещаний. Работами многих исследователей установлено, что неотектонические движения являются более сложными, чем это предполагалось еще несколько лет тому назад. На платформах неотектонические движения часто обнаруживают блоковой характер. О блоковом характере неотектонических движений говорят также более чем двадцатилетние исследования автора, проведенные на территории Әстонии. Впервые вывод о блоковом характере неотектонических движений земной коры Эстонии был нами сделан в 1958 г. на основе изучения строения и распространения озов Северной Эстонии (Ряхни, 1960). Позже это мнение подтвердилось при изучении ленточных глин в СевероВосточной Эстонии (Ряхни, 1963).

Благодаря большому количеству глубоких буровых скважин, достигших кристаллического фундамента, и детальных геофизических исследований, выполненных Институтом геологии АН ЭССР и Управлением геологии СМ ЭССР, к настоящему времени наши знания о тектоническом строении кристаллического фундамента и осадочного чехла Эстонии значительно расширились. Это позволяет полнее обосновать также блоковый характер неотектонических движений на территории Эстонии, особенно унаследованных от более древних тектонических движений.

Для этого нами было проведено сопоставление различных форм рельефа со схемой разломов кристаллического фундамента ЭССР, составленной сотрудниками Института геологии АН ӘССР Э. Побулем и Р. Вахером (Побул, Сильдвээ, 1973) и основные черты которой воспроизведены на рис. $1-3$. Кристаллический фундамент Эстонии разбит на отдельные блоки относительно небольших размеров, ограниченные тектоническими нарушениями (сбросами). Последние четко выявлены магнитометрическими и гравиметрическими методами и имеют обычно северо-восточное, реже северо-западное или субширотное простирания. Как эти блоки отражаются в тектоническом строении осадочного чехла, окончательно еще не выяснено, однако до сих пор установленные в осадочном чехле тектонические нарушения тесно связаны с нарушениями в кристаллическом фундаменте (Вахер и др., 1962).

На связь ледниковых образований Эстонии с тектоническими структурами указывал уже Э. Kраус (Kraus, 1928). К. Каяк (1963) обратил внимание на приуроченность ледниковых образований Ийзаку--Иллука 


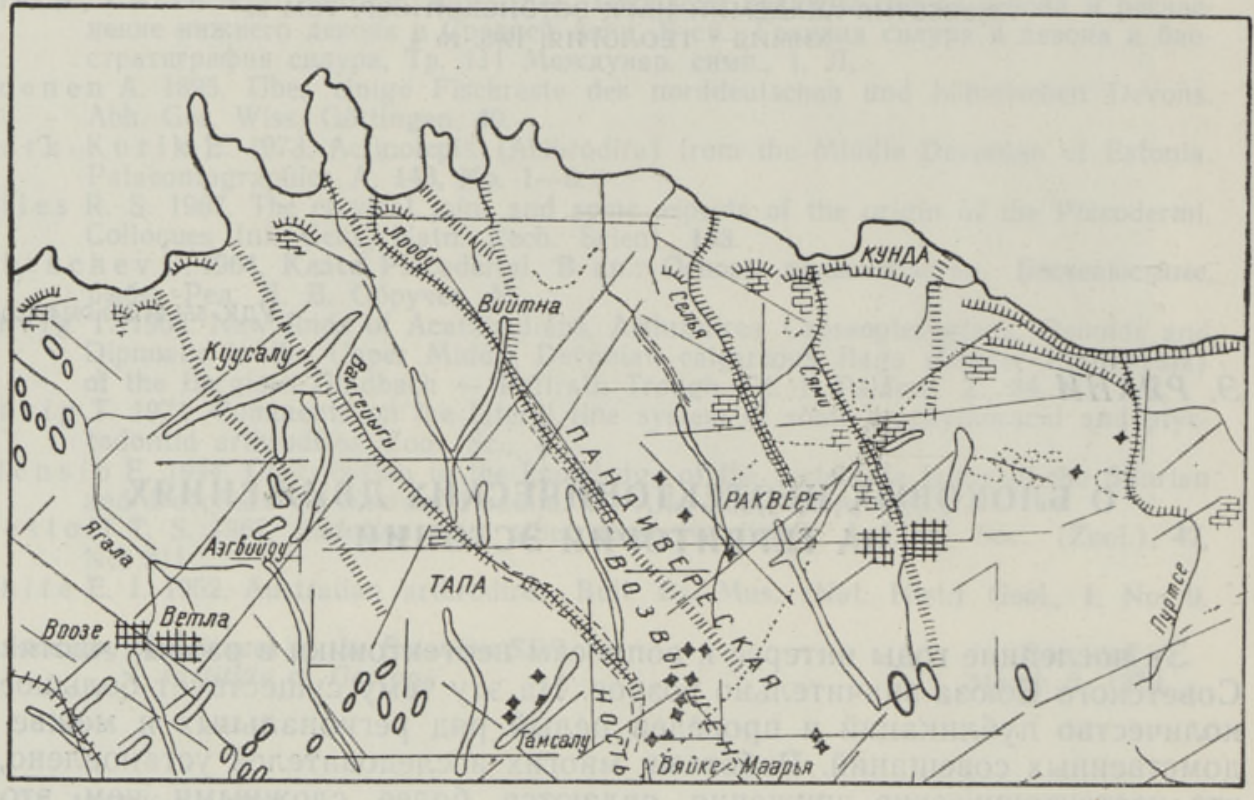

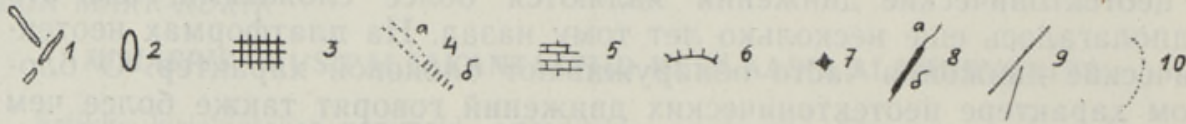

Рис. 1. Схема расположения нанболее важных форм рельефа последнего оледенения, древних погребенных долин и элементов тектоники в кристаллическом фундаменте и палеозойских породах Северной Эстонии. (Составлена автором с использованием материалов Э. Побула и Р. Вахера (см. Побул, Сильдвээ, 1973).)

1 - озы и конечные морены, 2 - друмлины, 3 - камы, 4 - а) речные и б) погребенные долины; 5 - альвары и районы с маломощным четвертичным покровом, 6 уступы, 7 - карст, 8 - а) реки и б) участки рек с аномальным падением, 9 - разломы в кристаллическом фундаменте, 10 - тектонические нарушения в палеозойских породах.

к тектоническим нарушениям ложа северо-западного простирания, а краевых форм рельефа Куремяги - к горстовой структуре осадочной толщи в данном районе. Несомненную связь с более древними тектоническими образованиями имеют также Вайвараские Синие горы (Каяк, 1963; Мийдел и др., 1969 и др.).

Карельскими (Бискэ, 1966 и др.) и финскими (Repo, 1957; Härme, 1961 и др.) исследователями обращено внимание на особенно хорошую связь, прослеживаемую между радиальными озами и тектоническими структурами. Наши наблюдения также показывают, что радиальные озы Северной Эстонии часто располагаются по границам блоков или в непосредственной близости от них. Это совпадение является отнюдь не случайным, а генетически обусловленным. По тектоническим нарушениям ложа интенсивные движения, вероятно, происходили еще в недалекое геологическое время. В позднем плейстоцене, во время отступания ледника последнего оледенения, они обусловливали появление трещин в ледниках, что в дальнейшем и привело к формированию озов. Местами (Аравете, Нээрути, Ийзаку и др.) в отложениях озов наблюдаются нарушения первичной слоистости амплитудами до 2 и и более, имеющие, по мнению автора, тектоническую природу. Они вызваны, по всей вероятности, не медленными тектоническими движениями, происходившими вдоль трещин, а кратковременными и весьма энергичными движениями, возможно даже землетрясениями. Ведь на территории Эстонии земле- 
трясения известны и в историческое время (Doss, 1905; Klaamann, 1964). Например, одно довольно сильное землетрясение (около 3-4 баллов) наблюдалось в районе Лаагна-Аувере-Мерекюла-Нарва 15 февраля $1884 \mathrm{r}$.

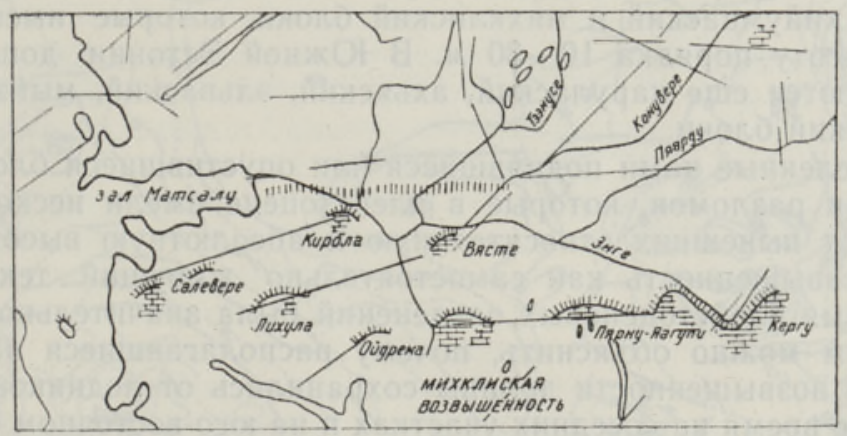

Рнс. 2. Схема расположения наиболее важных форм рельефа последнего оледенения, древних погребенных долин и элементов тектоники в кристаллическом фундаменте и палеозойских породах Западной Эстонии. Условные обозначения см. на рис. 1.

По данным А. Мийдела (1963), в речных долинах Эстонии имеются отдельные аномальные со значительно превышающим нормальное падение участки, которые образуют пороги. Эти участки, как показывают наши исследования, в большинстве случаев совпадают с неотектонически активными зонами дробления вдоль границ блоков в фундаменте (например, среднее течение рр. Пыльтсамаа и Пэдья, ряд участков на рр. Навести и Пярну (рис. 3) и др.). Следует отметить, что многие речные долины Әстонии проходят по тектоническим разломам, бывшим активными в голоцене, причем чаще это наблюдается у рек Северной Эстонии. Резкие повороты долин при этом чаще всего соответствуют местам пересечения зон разломов или трещиноватости (реки Энге, Коновере, Пирита, Ягала, Пярну, Валгейыги и др.). В простирании древних долин нередко наблюдается внезапное их исчезновение, что в большинстве случаев связано с границами блоков фундамента, установленными геофизическими методами и активными в неотектоническое время (например, древние долины на сакаласком и ахьяском блоках).

Рис. 3. Схема рапположения наиболее важных форм рельефа последнего оледенения, древних погребенных долин и элементов тектоники в кристаллическом фундаменте и палеозойских породах Сакалаской возвышенности.

Условные обозначения ом. на рис. 1.

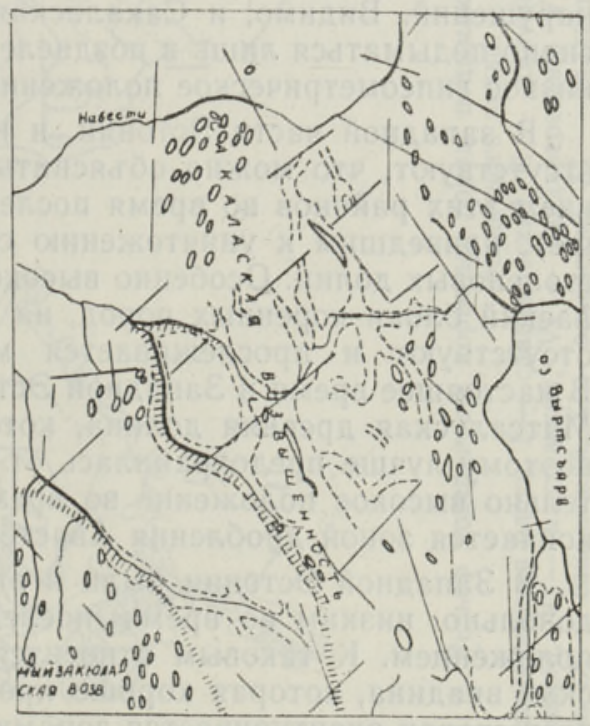

Остановимся коротко на рельефе поверхности коренных пород Эстонии. Обычно (Орвику, 1955 и др.) здесь выделяются Пандивереская, 
Сакалаская, Угандиская и Хааньяская возвышенности, которые, по мнению автора, соответствуют крупным тектоническим блокам. Однако блоков коренных пород значительно больше (рис. 4). Так, в Северной Эстонии, кроме обширной Пандивереской возвышенности, четко выделяются еще йыхвиский, варболаский и махтраский, а в Западной Эстонии сааремааский, хийумааский и михклиский блоки, которые имеют относительную высоту порядка $10-30$ м. В Южной Эстонии дополнительно прослеживаются еще карулаский, ахьяский, эльваский, мыйзакюлаский и калластеский блоки.

Все выделенные нами поднявшиеся или опустившиеся блоки ограничены зонами разломов, которые в плейстоцене имели несколько отличающиеся от нынешних относительную и абсолютную высоты. Пандивереская возвышенность как самостоятельно живущий тектонический блок во время плейстоценовых оледенений была значительно ниже, чем сейчас. Этим можно объяснить, почему располагавшиеся на северном склоне этой возвышенности долины сохранились от ледниковой экзарации. В то же время на соседних участках и на юго-восточном склоне возвышенности долины почти полностью уничтожены ледниками. То же самое можно сказать относительно угандиского и йыхвиского блоков. Лишь более низкое по сравнению с соседними районами положение этих блоков во время последнего и предпоследнего оледенений сохранило здешние долины от полной экзарации. Эти блоки стали интенсивно подниматься после отступания ледника. В то же время Хааньяская возвышенность, по всей вероятности, в течение всего плейстоцена имела тенденцию к поднятию (Можаев, 1969; Шульц, 1958). Древние долины здесь резко обрываются, а в центральной части возвышенности отсутствуют вовсе.

В пределах Сакалаской возвышенности погребенных древних долин известно мало. Древние долины, лишь частично заполненные отложениями, как правило хорошо прослеживаются в современном рельефе этого района (Каркси, Кыпу-Ыйзу, Раудна-Пайсту, ОлуствереПайсту и др.). Все они связаны с зонами разломов. Так, Вильяндиская древняя долина находится непосредственно над зоной тектонических нарушений. Видимо, и Сакалаская возвышенность стала более интенсивно подыматься лишь в позднеледниковое время, занимая ранее более низкое гипсометрическое положение.

В западной части Әстонии и на островах древние долины почти отсутствуют, что можно объяснить высоким гипсометрическим положением этих районов во время последнего оледенения (возможно и раньше), приведшим к уничтожению существовавших здесь ранее доплейстоценовых долин. Особенно высоко располагались махтраский и варболаский блоки коренных пород, на которых древние долины совершенно отсутствуют и прослеживается много форм ледниковой экзарации. В настоящее время в Западной Эстонии сохранилась всего лишь одна Матсалуская древняя долина, которая имеет широтное простирание и поэтому лучше предохранилась от экзарации, несмотря на свое относительно высокое положение во время оледенений; на востоке она резко кончается зоной дробления Авасте-Куусалу.

В Западной Әстонии были и опускавшиеся в плейстоцене районы с довольно низким во время последнего оледенения гипсометрическим положением. К таковым относится, например, прегляциальная Пярнуская впадина, которая хорошо прослеживается в древнем рельефе и со всех сторон оконтуривается зонами разломов (рис. 4). Судя по резкому понижению древнего рельефа несколько восточнее от полуострова Сырве, можно предположить, что и здесь находится относительно глубокая 


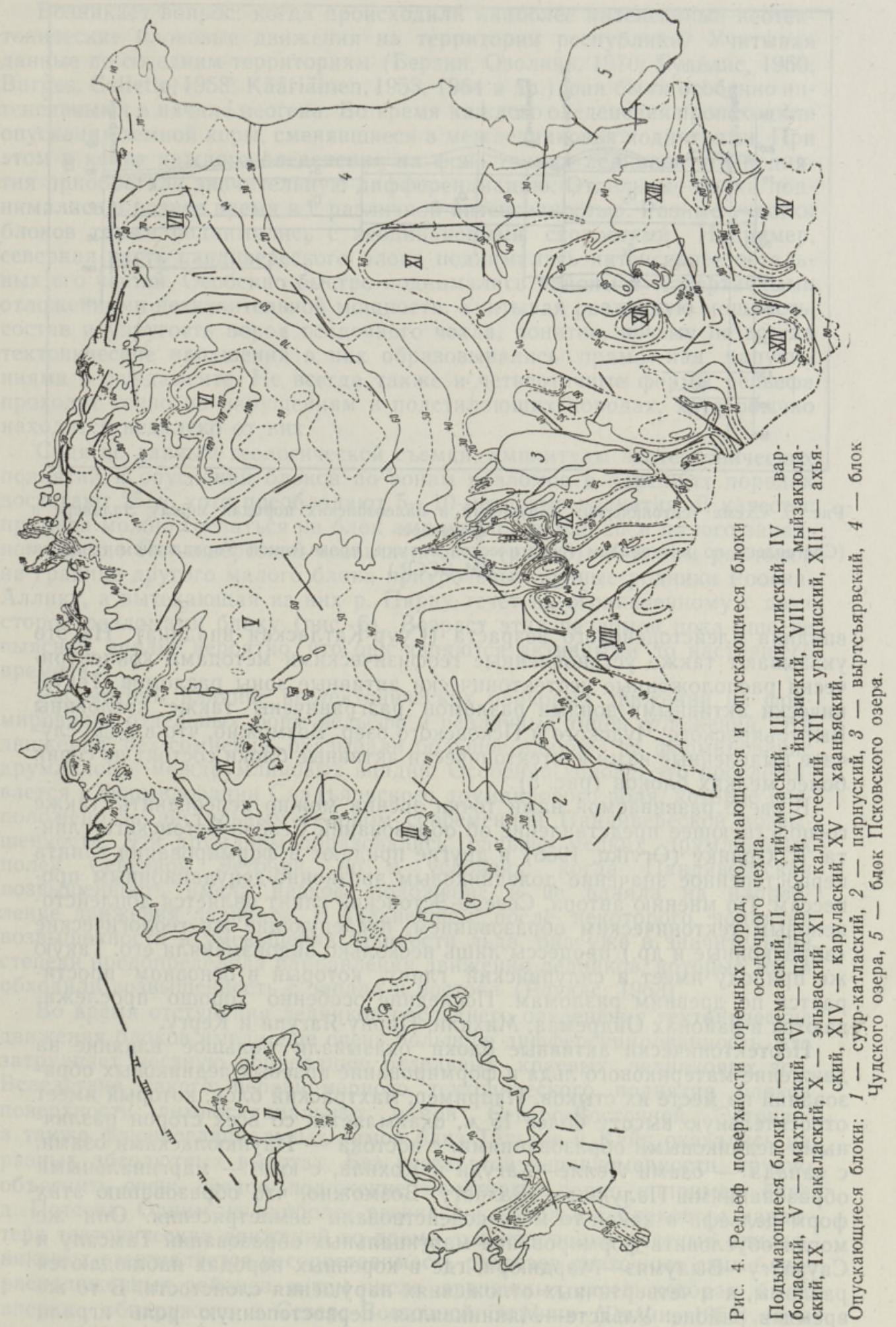




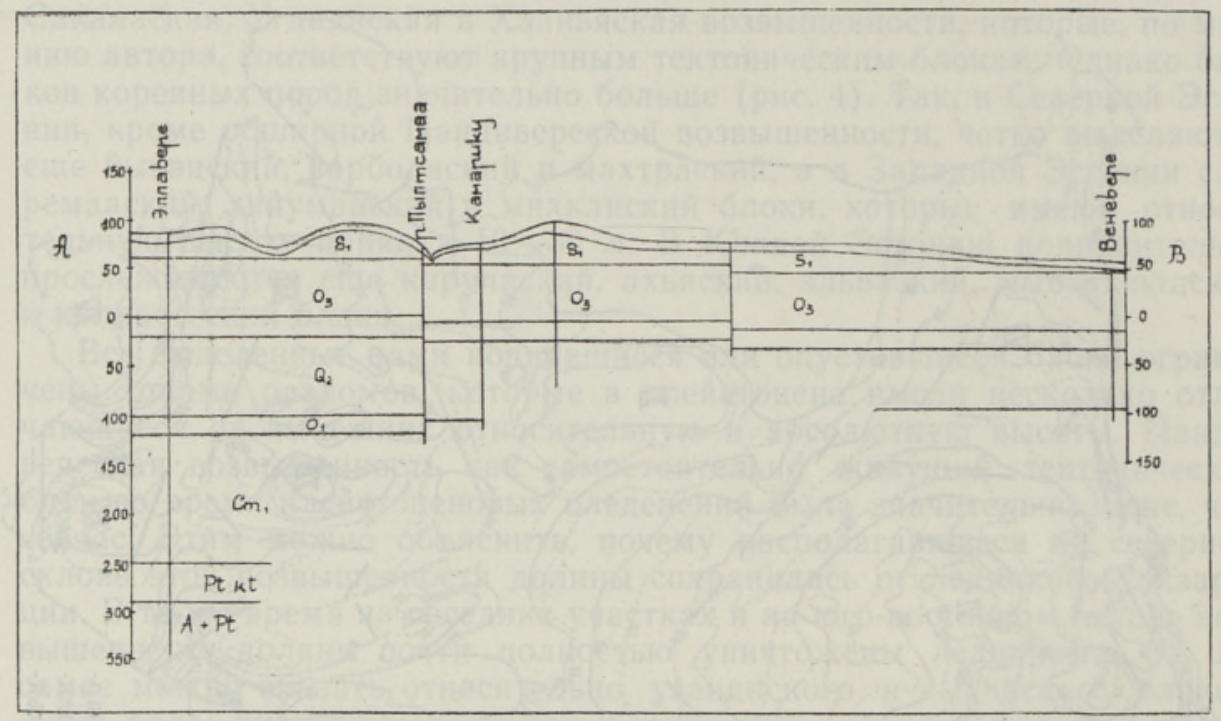

Рис. 5. Схема тектонических нарушений в палеозойских породах между Эллавере и Веневере.

(Составлена по материалам геологической съемки, проведенной Управлением геологии CM ЭСCP.)

впадина плейстоценового возраста (Суур-Катлаская впадина). На это указывают также установленные геофизическими методами концентрически расположенные неотектонически активные зоны разломов. Тектонически активными зонами разломов разграничены также котловины Выртсъярвского, Чудского и Псковского озер. Возможно, что в ряде случаев выделенные нами неотектонически активные блоки состоят из серии более мелких блоков (рис. 5).

В свете развиваемой нами точки зрения можно переоценить также господствующее представление об образовании Северо-Эстонского глинта. К. Орвику (Orviku, 1958) и другие придают в формировании глинта первостепенное значение доледниковым эрозионно-денудационным процессам. По мнению автора, Северо-Эстонский глинт является доплейстоценовым тектоническим образованием, последующие же геологические (абразионные и др.) процессы лишь несколько видоизменяли его. Такую же природу имеет и силурийский глинт, который в основном простирается по древним разломам. Последние особенно хорошо прослеживаются в районах Ойдремаа, Михкли, Пярну-Яагупи и Кергу.

Неотектонически активные блоки оказывали большое влияние на движение материкового льда и формирование краевых ледниковых образований на месте их стыков. Например, махтраский блок, который имеет относительную высоту более $15 \mathrm{M}$, окаймляется со всех сторон различными ледниковыми образованиями: с востока - Паункюласкими озами, с запада - озами Лелле-Хагуди и Кохила, с юга - маргинальными образованиями Палукюла-Вахасту. Возможно, что образованию этих форм рельефа в какой-то мере содействовали землетрясения. Они же могли обусловить формирование маргинальных образований Тамсалу и Сауэаугу-Вылумяэ-Мардиюри, где в коренных породах наблюдаются разломы, а в четвертичных отложениях нарушения слонстости. В то же время в районе Ульясте-Мянниквялья первостепенную роль играли медленные плейстоценовые тектонические движения. 
Возникает вопрос: когда происходили наиболее интенсивные неотектонические блоковые движения на территории республики? Учитывая данные по соседним территориям (Берзин, Озолинь, 1970; Гуделис, 1960; Burges, Collette, 1958; Kääriäinen, 1953, 1964 и др.), они были особенно интенсивными в начале неогена. Во время каждого оледенения происходили опускания земной коры, сменявшиеся в межледниковья поднятиями. При этом в конце каждого оледенения на фоне таяния ледников эти поднятия приобретали значительную дифференциацию. Отдельные блоки поднимались в разное время и с различной интенсивностью. Разные участки блоков также поднимались с неодинаковыми скоростями. Например, северная часть пандивереского блока поднималась интенсивнее остальных его частей. Особенно быстро поднимались районы с четвертичными отложениями незначительной мощности. Учитывая различную мощность, состав и упругость пород осадочного чехла, понятно, почему не всегда тектонические нарушения в них образовывались прямо над нарушениями в фундаменте. Не всегда также и четвертичные формы рельефа проходят точно по нарушениям в подстилающих породах, хотя обычно находятся недалеко от них.

Судя по данным геологической съемки, амплитуды неотектонических поднятий и опусканий блоков по зонам разломов в коренных породах достигают 25 м, хотя преобладают 5-10-метровые поднятия. В качестве примера можно сослаться на блок амплитудой около $20 \mathrm{~m}$ на юго-западном склоне Пандивереской возвышенности (рис. 5). К зонам разломов на границе другого малого блока приурочены крупные родники РооснаАллику, а вытекающая из них р. Пярну течет по ограниченному с двух сторон разломами блоку (рис. 6). Возраст этих разломов пока еще не выяснен, вполне вероятно, что они являются активными до настоящего времени.

Рассмотрим влияние неотектонических блоковых движений на формирование отдельных форм рельефа и различных типов отложений. Эти движения, без сомнения, оказывали большое влияние на формирование друмлинов и междрумлиновых впадин. Особенно хорошо это прослеживается в формировании Саадъярвского друмлинового поля, которое расположено за дистальным склоном современной Пандивереской возвышенности. Эти друмлины образовались раньше мелких друмлиновых полей Северной Эстонии, но в условиях, когда Пандивереская возвышенность имела низкое положение и не влияла на направление движения ледников. В дальнейшем, после некоторого поднятия возвышенности и уменьшения мошности льда, она уже в значительной степени предопределяла направления движения ледников, которые тогда обходили возвышенность с запада и востока (Раукас, 1963).

Во время отступания ледников последнего оледенения тектонические движения блоков имели еще очень большую дифференцированность, что затрудняет местную корреляцию отдельных краевых ледниковых зон. Вследствие такого неравномерного тектонического поднятия блоков поверхности лимногляциальных камов Северо-Восточной Эстонии, а также флювиогляциальных камов близ Тёльязе и Кайу оказались на разных абсолютных высотах. Без учета этой неравномерности трудно объяснить очень низкое положение некоторых дельт, например, близ д. Потсепа. Одним из наиболее веских доказательств блокового характера тектонических движений во время существования местных приледниковых озер является несопоставимость разрезов ленточных глин близрасположенных районов, в том числе дренажных слоев, которая была впервые обнаружена в Северо-Восточной Эстонии (Ряхни, 1963), а в дальнейшем и в Западной Эстонии. Так, например, никак не увязы- 
ваются друг с другом разрезы близ д. Лепплаане и пос. Синди, расстояние между которыми составляет около $10 \kappa м$, и даже отстоящие друг от друга на 2 км разрезы близ дд. Лепплаане и Метсакюла. Обусловлена эта неувязка тем, что данные разрезы располагаются в пределах разных блоков (михклиского и пярнуского), поднимающихся с разной скоростью и разделенных широкой зоной тектонических нарушений, простирающейся от Пярну до Нарвы (Орвику, 1960). По данным изучения ленточных глин и флювиогляциальных дельт, амплитуды существовавших с позднеледникового времени движений не превышают 8-10

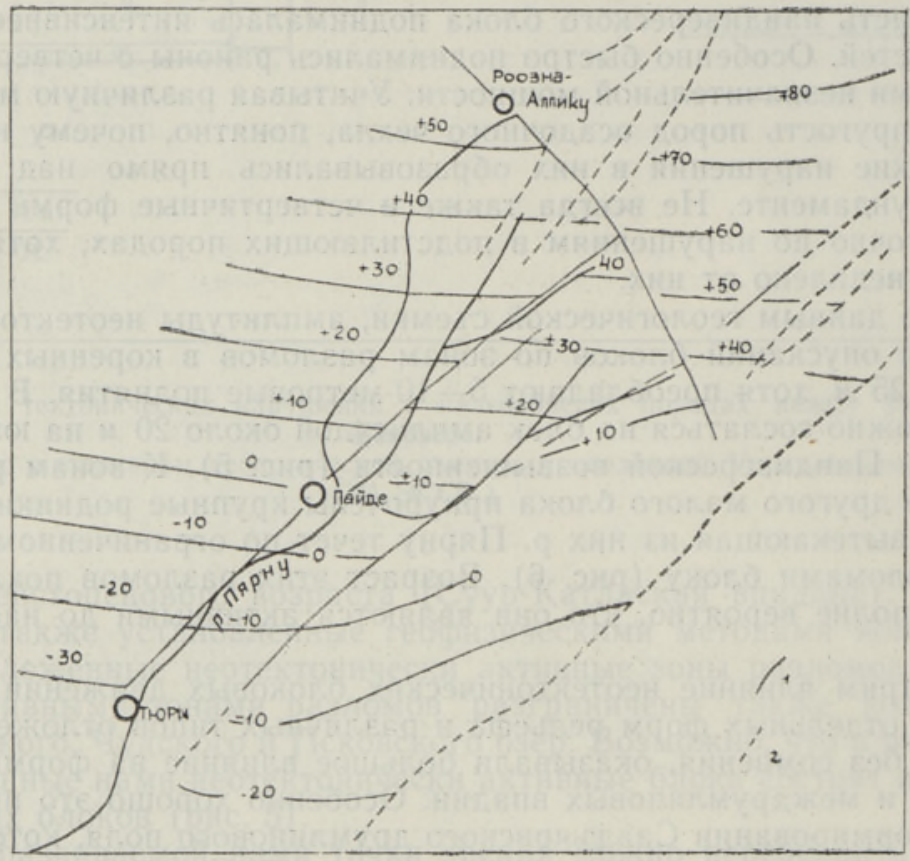

Рис, 6. Изобазы подошвы силура.

1 - тектонические разломы, выявленные бурением и геофизи. ческими методами; 2 - тектонические разломы, выявленные геофизическими методами.

(Составлены по материалам геологической съемки, проведенной Управлением геологии СМ ЭССР.)

В голоценовых береговых образованиях соответствующие различия еще менее значительны (не более 2 м), что говорит о постепенном затухании этих дифференцированных тектонических движений. Возможно, что отчасти это обусловлено удаленностью наиболее интенсивно поднимающихся или опускающихся блоков от голоценовых береговых образований Балтики.

Как известно, карст в Северной Эстонии тесно связан с трещиноватостью в горных породах и особенно сильно проявляется в зонах тектонических нарушений (Андра, Хейнсалу, 1966). По мнению автора, карстовые проявления приурочены преимущественно к зонам тектонически активных нарушений, например, в районе Вяйке-Маарья-Раквере к зоне нарушений Азери-Койги. В Северо-Восточной Эстонии, западнее от гряды Йизаку-Иллука, карстовых проявлений очень мало, но к востоку от гряды они распространены весьма широко. Это говорит в пользу того, что блок к северу от Чудского озера (к востоку от р. Алайыги) в 
поздне- и послеледниковое время поднимался по сравнению с соседними районами сравнительно медленно. В то же время западнее от этой линии наблюдаются большие скорости поднятия. Об этом говорят интенсивная донная эрозия р. Ранна-Пунгерья и быстрое поднятие берега Чудского озера между пос. Ранна-Пунгерья и Раадна. Большое падение и интенсивная донная эрозия наблюдаются также у рек Омеду и Муствээ.

Отдельные районы, наоборот, очень быстро опускаются. Например, близ д. Будовича (южная часть Псковского озера), по данным повторных нивелировок и топографических картирований, земная кора опустилась в течение последних 50 лет не менее чем на $15-25$ см.

Суммируя все имеющиеся данные относительно скоростей движения отдельных блоков, можно предположить, что наиболее подвижными были хааньяский и пандивереский блоки, которые в течение последних 12-13 тыс. лет поднялись не менее чем на 30 м. Блоки Западной Эстонии за это время поднялись на $10-20 \mu$. Не меньшую амплитуду $(10-20$ м) имели опустившиеся блоки (пярнуский, суур-катлаский, ахьяский).

В заключение необходимо отметить, что некоторые наши выводы имеют гипотетический характер и еще недостаточно подкреплены конкретным фактическим материалом. Поэтому в ближайшее время необходимо заложить ряд новых геофизических и геодезических полигонов (прежде всего близ гг. Пярну и Отепя, а также по южному берегу Псковского озера) и более детально изучить тектонические нарушения в подстилающих породах вдоль озовых систем Северной Әстонии, используя для этой цели бурение и геофизические методы.

\section{ЛИТЕРАТУРА}

Анд р а Х., Хейнсалу Ю. 1966. Древняя долина и карст по зоне трещиноватости северо-западного простирания в окрестностях Поркуни (Северная Эстония). Изв. АН ЭССР, Сер. физ.-матем. и техн. н., XV, № 3.

Би ск э Г. С., Г ор юн о в а Н. Н., Л ак Г. Ц. 1966. Новые данные о четвертичных отложениях и неотектонике Онего-Сегозерского водораздела. В кн.: Вопросы геологии и закон, размещения полезных ископаемых Карелии. Петрозаводск.

Бе р зинь Л. Э., О з олин ь Н. К. 1970. Строение фундамента территорин Центральной и Западной Латвии по геофизическим данным. Нефтепоисковые критерии Прибалтики и методы их изучения. Тр. Ин-та геол., вып. 8. Вильнюс.

В а хе р Р. М., П у ур а В. А., Э р и са лу Э. К. 1962. Тектоническое строение СевероВосточной Эстонии. Тр. Нн-та геол. АН ЭССР, Х.

Г удел и с В. К. 1960 . О реакции земной коры на процессы гляциации и дегляциации. В сб.: Неотектонические движения в Прибалтике. Тарту.

Каяк К. Ф, 1963. О краевых ледниковых образованиях юго-восточной Әстонии. Тр. Комисс. по изуч. четв. периода, XXI. М.

Ми йдел А., П а а п Ю., Р а ук а с А., Р я хн и Э. 1969. К вопросу о происхождении Вайвараских Синих гор (Северо-Восточная Эстония). Изв. АН ЭССР, Геол. Хим., 18, № 4.

Ми йдел А. М. 1963. Распределение падений рек Северной Эстонии. Тр. Ин-та геол. $\mathrm{AH} \ni \mathrm{CCP}, \mathbf{X I I}$.

Мож а е в Б. Н. 1969. История новейшего тектонического развития северо-запада Русской равнины. Изв. АН СССР, Сер. геогр., вып. 2.

Н икол а в Н. М. 1967. О новейшем этапе развития Фенноскандии, Кольского полуострова и Карелии. Бюлл. Московск. об-ва исп. природы, Отд. геол., XII (1).

О р в и ку К. К. 1955. Основные черты геологического развития территории Эстонской CCP в антропогеновом периоде. Изв. АН ЭСCP, IV, № 2.

О р в и ку К. 1960. О неотектонических движениях в Эстонской ССР на основе геологических данных. Мат-лы совещ. по вопр. неотектон. движений в Прибалтике. Тарту.

П об ул Э., Си льдвээ Х. 1973. О разрывных нарушениях кристаллического фундамента Эстонии. Изв. АН ЭССР. Хим. Геол., 22, № 1.

Р а ук а с А. 1963. Распространение руководящих валунов в моренах последнего оледенения Эстонской ССР. Изв. АН ЭССР, Сер. физ.-матем. и техн. н. ХII, № 2. 
Р я хни Э. Э. 1960. О генезисе озов Северной Эстонии. Тр. Ин-та геол. АН ЭССР, V. Таллин.

Р яхни Э. Э. 1963. Геохронология ленточных глин северо-восточной Эстонии. Тр. Ин-та геол. АН ЭССР, XII.

Шульц С. С. 1958. Новейшая тектоника, Русская платформа. В сб.: Геологическое строение СССР. Тектоника, 3. М.

Burges I. M., Coll et te B. 1958. On the problem of postglacial uplift of Fennoskandia. Proc. K. nedrl, akad. wetensch, Ser. B, 61, No. 4.

D o s s B. 1905. Uber ein unbeachtet gebliebenes Beben in Estland. Korresp. Bl. Naturf. Ver. Riga.

$\mathrm{H}$ ärm e M. 1961. On the fault lines in Finland. Com. R. Soc. Geol. Finl., XXXIII, No. 196.

K 1 a a m a n n E. 1964. Maavärinaist Eestis. Eesti Loodus, nr. 4.

Kraus E. 1928. Tertiär und Quartär des Ostbaltikums. Ostbaltikum T. Z. Berlin, Borntraeger.

$\mathrm{Kääri} a ̈ \mathrm{i}$ en E. 1953. On the recent uplift of the Earth's crust in Finland. Fennia, 77, No. 2.

Kääriäinen E. 1964. Land uplift in Finland computed by the aid of precise levellings. Fennia, 89, Nr. 1.

Orviku K. 1958. Kuidas tekkis Pōhja-Eesti paekallas? Rahva Hääl, 28, aug.

Re p o R. 1057. Untersuchungen über die Bewegungen des Inlandeises in Nordkarelien. Bull. Commiss. géol. Finlande, No. 179.

Ннститут геологии

Академии наук Эстонской ССР
Поступила в редакцию

$18 /$ IX 1972

\section{E. RAHNI}

\section{NEOTEKTOONILISTEST PANKALISTEST LIIKUMISTEST EESTI TERRITOORIUMIL}

Mandrijää servamoodustistel, eriti oosidel, on tihe seos aluspōhja tektooniliselt aktiivsete purustusvöönditega (joon. 1). Ka paljud jōeorud kulgevad tektooniliselt aktiivsetel purustusvöönditel (joon. 2 ja 3) ning jōgede kiirema languse lōigud paiknevad tektooniliste plokkide äärealadel. Tektoonilised plokid, mis tänapäeval kujutavad enestest aluspōhjalisi kōrgendikke ja vagumusi ( $\mathrm{I}-\mathrm{XV}$ ja $1-5$, joon. 4), on tekkinud peamiselt tektooniliste diferentseeritud liikumiste tulemusena. Pleistotseenis paiknesid mōned plokid madalamal kui praegu, mistōttu preglatsiaalsed orud nende piires jäid liustiku ründe eest varjatuks, mujal aga kulutati nad ära. Plokkide suhtelised tasememuutused ulatuvad kümnetesse meetritesse (joon. 5 ja 6). Mandrijää taandumise ajal hilisglatsiaalis ja viirsavide ning fluvioglatsiaalsete deltade tekke ajal olid diferentseeritud liikumised intensiivsemad (kokku 8-10 m) kui holotseenis (kokku mitte üle $2 \mathrm{~m}$ ).

\section{E. RA $\bar{H} N I$}

\section{ON THE NEOTECTONIC BLOCK MOVEMENTS OF THE EARTH'S CRUST ON THE TERRITORY OF ESTONIA}

The marginal glacial formations, the eskers in particular, have a close connection with tectonically active breaking zones of the bedrock (Fig. 1). Many river valleys run in tectonically active zones (Figs 2 and 3 ) and the river sections containing rapids are placed in the marginal areas of the tectonic blocks. Tectonic blocks that nowadays represent bedrock elevations and ancient valleys ( $\mathrm{I}-\mathrm{XV}$ and $1-5$, Fig. 4) have basically originated as a result of tectonically differentiated movements. During the Late Pleistocene some blocks were at lower positions than nowadays, and therefore the preglacial valleys within their limits were protected from the attack of the glacier, whereas elsewhere they were denudated.

In the postglacial time, when the varved clays and fluvioglacial deposits were accumulated, the neotectonic movements were more intensive than in the Holocene, the postglacial total amounting to $8-10 \mathrm{~m}$, whereas the Holocene total does not exceed $2 \mathrm{~m}$. 